\title{
Effect of Magnetic Field and Moringa Seed Powder on Wastewater Treatment
}

\author{
1*YUSUF, KO; ${ }^{2}$ OBALOWU, RO; ${ }^{1 a}$ ABUBAKAR, A \\ ${ }^{*}$ Department of Agricultural and Biosystems Engineering, University of Ilorin, Ilorin, Kwara State, Nigeria \\ ${ }^{2}$ Department of Agricultural and Bio-Environmental Engineering Technology. Institute of Technology, Kwara State Polytechnic, Ilorin, \\ Nigeria \\ *Corresponding author: kamaru.yusuf@yahoo.com; yusuf.ok@unilorin.edu.ng \\ Other Authors Email: abrashaola@gmail.com; aminatololade3@gmail.com
}

\begin{abstract}
This study was conducted to determine the effect of magnetic field (MF) and moringa seed powder (MSP) on wastewater treatment. Wastewater causes environmental and river pollution that are harmful to aquatic animals and toxic to man. Domestic wastewater was collected from the bathroom, University of Ilorin male hostel (Compound G). The wastewater was divided into four portions. First portion was allowed to flow through MF (100 mT) for 40, 60 and 80s. Second portion, 4 litres of the wastewater was poured into 5 litres capacity containers and 100,150 and $200 \mathrm{mg} / \mathrm{L}$ of MSP was added to each container with 2 replicates. Third portion, 100,150 and $200 \mathrm{mg} / \mathrm{L}$ of MSP was added to the wastewater after the wastewater was passed through MF for 40, 60 and $80 \mathrm{~s}$ and the fourth portion was the control experiment. Physical, chemical and bacteriological properties of the wastewater were determined after 2 hours. The range of reduction in turbidity for MSP, MF, combination of MSP and MF compared with the control experiment were 3.08-18.46, 9.00-23.08 and 20.03-23.08\%, respectively. Reductions of total coliform were $84.21-88.42 \%, 36.84-47.37 \%$ and $75.26-87.89 \%$. The range in reduction ammonia nitrate for MSP, MF, combination of MSP and MF compared with control experiment were 2.96-9.63, 0.00-1.48 and 6.67-8.89\%. The values of BOD were 0.82-7.14, 0.822.45 and $2.24-8.37 \%$. The results indicated that combination of MF and MSP reduced physicochemical and bacteriological properties of the wastewater. Combination of MSP and MF is recommended for treating wastewater before discharging into rivers.
\end{abstract}

DOI: $\underline{\text { https://dx.doi.org/10.4314/jasem.v24i2.22 }}$

Copyright: Copyright $(2020$ Yusuf et al. This is an open access article distributed under the Creative Commons Attribution License (CCL), which permits unrestricted use, distribution, and reproduction in any medium, provided the original work is properly cited.

Dates: Received: 16 November 2019; Revised: 11 January 2020; Accepted: 22 February 2020

Keywords: wastewater, wastewater treatment, moringa, magnetized wastewater, water pollution

Wastewater is the water that has been contaminated by impurities, chemicals and pathogens which could be harmful to man and environment. Major sources of wastewater are textile industries, pharmaceutical industries, paper industries, toilet, kitchen, car washing places, insecticides, herbicides from agricultural areas, dumping of dead animals into the rivers and surface runoff flowing from contaminated areas into the streams and rivers. Domestic wastewater in Ilorin and most parts of Nigeria are not commonly treated before discharging into rivers and nearby streams. Discharging of wastewater into river normally causes water pollution in the area and affecting the aquatic animals. Both industrial and domestic wastewater causes water pollution if not treated before discharging into streams, rivers and lakes. The quality of freshwater from underground and pond water which are the major sources of drinking in rural areas is no more available and have been contaminated due to pollution by domestic, industrial and agricultural wastes. Water pollution is a serious problem not only in developing countries but in the entire world and it has contributed negatively to environmental degradation and human health (Briggs, 2003). Water pollution had been reported to cause some deadly diseases and could accounts for death of more than 14,000 people daily globally (West, 2006). Equipment and facilities for treating wastewater in some developing countries like Nigeria especially in the rural areas and even urban areas are rarely available. There is need for the development of simple equipment or facilities for treating domestic wastewater before discharging it into nearby streams and rivers to reduce environmental and river pollution. Availability of simple equipment could reduce the cost of treating surface water and reduce water borne diseases among the rural dwellers that depend on streams, rivers and drink the polluted surface water (contaminated water) at the downstream of the river without any treatment. Magnetic field has been used for treatment of several common wastewaters. For instance, magnetic field were applied for the treatment of leachate (Mdsa'at, 2006), turbidity and suspended solids and organic compounds (Lebkowska et al., 2011), nutrients consisting of nitrogen and phosphorus compound (Liu 2008) and toxic chemical (Jung et al., 1997) from wastewater. Alkhazan and Sadddiq (2010) used magnetic field for treating lake water which had effect on the physical, chemical and microbiological properties of the lake water in Saudi Arabia. Othman et al. (2009) stated that magnetic treatment of landfill leachate improved the removal of suspended solid, chemical oxygen demand and biochemical oxygen demand by 60 to $80 \%$ using a magnetic field strength of $550 \mathrm{mT}$. Anne et al. (2016) also pointed out that magnetic fields of $2 \mathrm{mT}, 6 \mathrm{mT}$ and $10 \mathrm{mT}$ reduced the number of E.Coli by 50.9, 65.5 and $82.2 \%$, respectively when compared to the control experiment after 6 hours of exposure to magnetic field. Kronenberg et al. (1985) reported that phenomenon of 
water treatment with the use of applied magnetic field has been known for many years and reported to be effective for treating irrigation water and wastewater. Sohaili et al. (2004) explained that magnetic technology is a promising treatment process that can enhance the separation of suspended particles from the sewage. Maheshwari and Grewal (2009) indicated that magnetic flux density ranging from 35 and 1360 gauss (G) which was measured inside the pipe was effective for treating irrigation water. The magnetic field must cuts across the wastewater flowing in the PVC pipe at right angle according to Fleming's right hand rule so that the wastewater could be magnetically treated otherwise there would be no effect of magnetic treatment. Podlesny et al. (2004) pointed out that the residence time for treating irrigation water magnetically by passing the water through magnetic field should be $15 \mathrm{~s}$ but Aladjadjiyan (2007) stated that 60 to $600 \mathrm{~s}$ was appropriate for effective magnetic treatment of water. Moringa Olefera seeds act as a natural absorbent and anti-microbial agent. The seeds contain $1 \%$ active polyelectrolyte's that could neutralize the negatively charged colloid in the dirty water. The seed has protein that is non-toxic, natural polypeptide which is good for sedimentation of mineral particles and organics in the purification of drinking water. Moringa olefera extracts produce lower sludge volumes when compared with aluminum. It also softens hard water and acts as a good adsorbent for cadmium (heavy metal that is toxic to kidney. Moringa is effective for the removal of physicochemical properties of water or wastewater and as adsorbent for organic substances and could considerably reduce the biological properties of water and wastewater (Bhuptawat et al., 2007). The objective of this study was to determine the effect of magnetic field and moringa seed powder on physical, chemical and bacteriological (total coliform) on wastewater treatment.

\section{MATERIALS AND METHODS}

Location of the study: The study was carried out at the Department of Agricultural and Biosystems Engineering, University of Ilorin, Ilorin, Nigeria between April and July, 2018. Ilorin is on latitude $8^{\circ} 30^{\prime} \mathrm{N}$ and longitude $4^{\circ} 35^{\prime} \mathrm{E}$ at an elevation of about $340 \mathrm{~m}$ above mean sea level (Ejieji and Adeniran, 2009). Ilorin is in the Southern Guinea Savannah Ecological Zone of Nigeria with mean annual rainfall of about $1300 \mathrm{~mm}$. The wet season begins towards the end of March and ends in October while the dry season starts in November and ends in March (Ogunlela, 2001).

Production of moringa oleifera seed powder: The ripped moringa oleifera pods were harvested and sundried for a week. The seeds were then removed from the pods, de-hulled and ground using grinding machine in order to have it in powder form. The seed powder was de-oiled using N-hexane as the reagent. The powdered seed was de-oiled because the presence of oil would hinder the coagulation effect of moringa for suspended particles in water. The de-oiled seed powder was then spread to dry at room temperature.

Moringa seed powder for treatment of the wastewater: The required quantity of moringa seed powder after weighing on the electric weighing balance was mixed with $100 \mathrm{~mL}$ of the wastewater to form a paste. The paste was then added to the wastewater to be treated in a transparent 5 litres capacity gallon in quantities (proportion) of 100, 150, $200 \mathrm{mg} / \mathrm{L}$. The wastewater with the moringa seed powder was then stirred rapidly for 1 minute, then slowly for another 10 minutes. The treated wastewater was allowed to settle down for 2 hours before samples were taken for the analyses.

Magnetic field unit for treatment of the wastewater: A rectangular wooden treatment chamber with a dimension of 7 by $12 \mathrm{~cm}$ was used to house the permanent magnets which were removed from the worn-out loud speaker. The magnets were arranged by the sides of a $1 / 2$ inch $(12.7 \mathrm{~mm})$ diameter PVC pipe through which the wastewater flows during the treatment in this study as shown in Figure 1. The mean effective magnetic flux density inside the PVC pipe was $100 \mathrm{mT}$ for the laboratory study. The magnetic flux density was measured using a gaussmeter, Model GM-2 by Alpha Lab Inc. The wastewater was poured inside a 15 litres plastic bucket connected with a hose to the magnetic treatment unit and to the collecting bucket as shown in Figure 2. The magnetic field cuts across the wastewater flowing in the PVC pipe at right angle for the wastewater to be magnetically treated.

The third portion of the wastewater after passing through magnetic field, it was poured into the transparent 5 litres capacity gallon ( 6 gallons, 2 for each moringa dosage) and 100, 150, $200 \mathrm{mg} / \mathrm{L}$ moringa seed powder were added to the wastewater. The wastewater with the moringa seed powder was then stirred rapidly for 1 minute, then, slowly for another 10 minutes. The treated wastewater was allowed to settle down for 2 hours before samples were taken for analyses. The fourth portion was the control experiment which was neither treated with moringa seed powder nor the magnetic field.

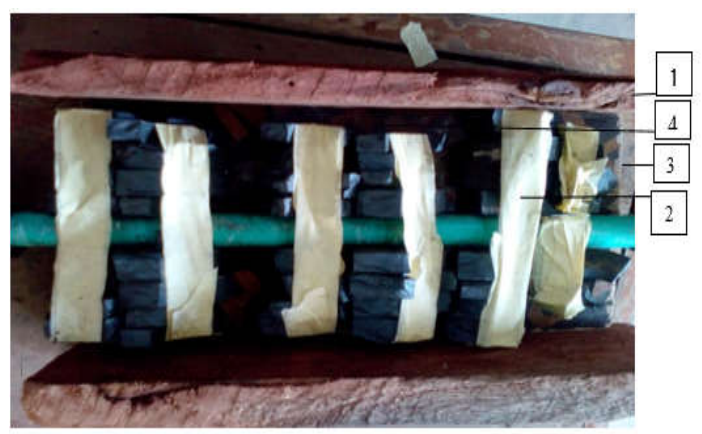

Fig 1. Arrangement of permanent magnet on the PVC pipe for the wastewater treatment: Legend: 1 = wooden housing, 2 = paper tape, $3=0.5$ inch $\mathrm{PVC}$ pipe, $4=$ permanent magnet 


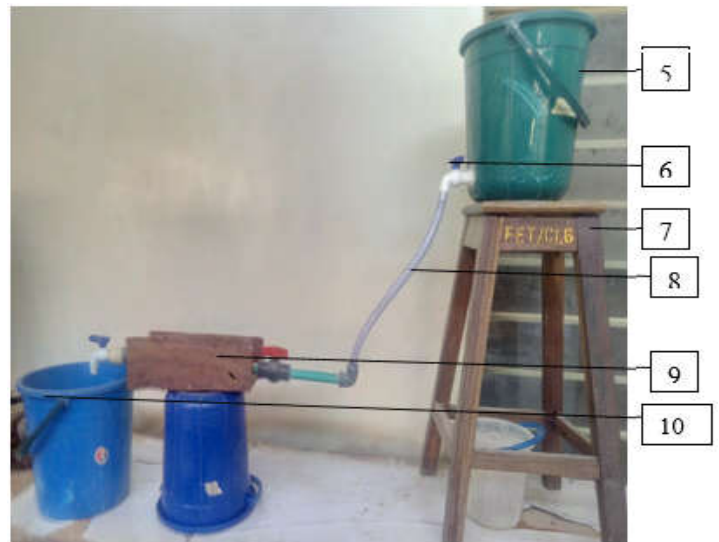

Fig 2. Magnetic treatment unit for the wastewater: Legend: $5=$ Storage tank, $6=$ control tap, $7=$ stood, $8=$ hose, $9=$ magnetic field unit, $10=$ collector for the wastewater

Parameters assessed from the wastewater: The parameters assessed were the physical, chemical and bacteriological properties of the wastewater. The parameters assessed in the wastewater were the turbidity, $\mathrm{pH}$, dissolved oxygen (DO), biochemical oxygen demand $\left(\mathrm{BOD}_{5}\right)$, chemical oxygen demand (COD), ammonia nitrate, sulphate ion, electrical conductivity, alkalinity and total coliform. The parameters were determined using the standard methods given by the American Public Health Association (APHA) (2005).

\section{RESULTS AND DISCUSSION}

The physical, chemical and bacteriological properties of the domestic wastewater before treatment (control experiment) and after the treated with magnet field, moringa seed powder and the combination of moringa seed powder and magnetic field were shown in Table 1.

The physical, chemical and bacteriological properties presented in Table 1 were the turbidity, $\mathrm{pH}$, dissolved oxygen (DO), biochemical oxygen demand $\left(\mathrm{BOD}_{5}\right)$, chemical oxygen demand (COD), ammonia nitrate, sulphate ion, electrical conductivity, alkalinity and total coliform. The mean values of each parameter were given in Table 1 (not-bolded) while the percentage reduction of the parameter was bolded in Table 1 . The values of turbidity with 100,150 and 200 $\mathrm{mg} / \mathrm{L}$ when only moringa seed powder was used to treat the domesticate wastewater were 6.30, 5.90 and $5.30 \mathrm{mg} / \mathrm{L}$, respectively but the value for the control experiment was $6.50 \mathrm{mg} / \mathrm{L}$. The results when the wastewater was allowed to flow through the magnetic field for 40, 60 and $80 \mathrm{~s}$, the turbidity values were 5.90, 5.80 and $5.00 \mathrm{mg} / \mathrm{L}$, respectively. The combination of moringa seed powder $(100,150,200 \mathrm{mg} / \mathrm{L})$ and magnetic field for 40,60 and $80 \mathrm{~s}$ gave consistent and better reduction in the values of the turbidity as 5.20 , 5.10 and $5.00 \mathrm{mg} / \mathrm{L}$. The combination of moringa seed powder and magnetic field also reduced the total coliform by $75.29-87.89 \%$ though moringa seed powder gave highest percentage reduction of total coliform $84.21-88.42 \%$ but not consistent like the combination of moringa seed powder and magnetic field as shown in Table 1. Other parameters assessed from the wastewater were shown in Table 1. The results of major physicochemical and total coliform are presented in Figure 3. From the results presented in Table 1, both moringa seed powder and magnetic field had effect on physical, chemical and bacteriological (total coliform) properties of wastewater. Magnetic field reduced the turbidity by $9.23,10.77$ and $23.08 \%$ when the wastewater was allowed to flow through magnetic flux density of 100 $\mathrm{mT}$ for 40, 60 and $80 \mathrm{~s}$, respectively which was in agreement with Sohaili et al. (2004) that magnetic treatment is a promising technology that could enhance the separation of suspended particles from the sewage. Moringa seed powder with 100, 150 and 200 $\mathrm{mg} / \mathrm{L}$ reduced the turbidity by $3.08,9.23$ and $18.46 \%$, respectively while the combination of moringa seed powder and magnetic field at 40,60 and $80 \mathrm{~s}$ were $20.00,21.54$ and $23.08 \%$. The results of moringa was in agreement with studies by Kumari et al. (2006) and Ghebremichael et al. (2005) which stated that seeds of moringa has good coagulant properties to flocculate particles and contain high amount of proteins that act like cationic polyelectrolytes when added to raw water. The results obtained was also in agreement with Joshua and Vasu (2013), Mustapha (2013) that moringa seed powder has ability to coagulate the floating particles in water which could lead_to the removal or reduction in turbidity of water. The combination of moringa seed powder and magnetic field in this study gave better results in percentage reduction of turbidity. Magnetic field had little effect on percentage reduction of $\mathrm{pH}$ of the wastewater by $0.59-1.32 \%$ but moringa seed powder reduced $\mathrm{pH}$ by higher percentage (3.69-5.59\%) followed by combination of moringa and magnetic field as shown in Table 1. Magnetic field was able to reduce the BOD and COD in the wastewater more than moringa seed powder only.

Combination of magnetic field and moringa seed powder reduced the BOD and COD more than when only magnetic field was used to treat the wastewater. The moringa seed powder reduced the ammonia nitrate and sulphate ion more than the magnetic field and the combination. Moringa seed powder was able to reduce the ammonia nitrate and sulphate ion because moringa is a good adsorbent material that could remove chemical pollutant from water and wastewater (Araújo et al., 2010). Magnetic field had little effect in reducing ammonia nitrate and sulphate ion and this could make the use of magnetic field in treating wastewater more useful for irrigating crops because it could reduce the turbidity, surface tension of wastewater and making more nitrate from ammonia available for crop growth and high yield. Moringa seed powder and the combination of magnetic field and moringa seed powder were able to reduce the total coliform by $84-88$ and $75-87.89 \%$, respectively. 


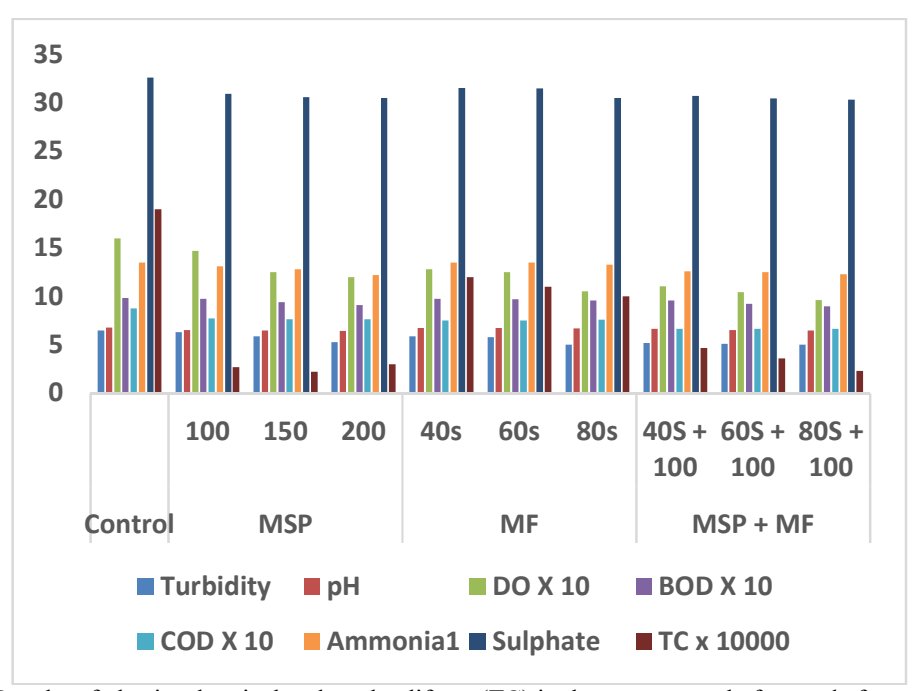

Fig 3. Results of physicochemical and total coliform (TC) in the wastewater before and after treatment $\mathrm{MSP}=$ Moringa seed powder at 100, 150 and $200 \mathrm{mg} / \mathrm{L}, \mathrm{MF}=$ Magnetic field used in 40,60 and $80 \mathrm{~s}$

Effect of magnetic field on wastewater reduced total coliform by $36.72-47.36 \%$. Moringa seed powder possesses antibacterial properties that for eliminating bacteria and it also acts as bio-adsorbent for heavy metal removal (Adelaja, et al 2011). Magnetic field reduced alkalinity better than the moringa seed powder as shown in Table 1 and this could make magnetic treatment of wastewater suitable for irrigation without causing soil salinity. The results of reduction in alkalinity was in agreement with results obtained by Ogunlela and Yusuf (2016) that magnetic field reduced the effect of concentration of sodium ion in irrigation water in magnetically treated water than non-magnetically treated water thereby reducing sodium adsorption ratio of irrigation water.

Table 1. Physicochemical and bacteriological properties of the wastewater before and after treated with moringa and magnetic field

\begin{tabular}{|c|c|c|c|c|c|c|c|c|c|c|}
\hline \multirow[t]{2}{*}{ Parameter assessed } & \multirow{2}{*}{$\begin{array}{l}\text { Control } \\
\text { experiment } \\
\text { (Wastewater } \\
\text { not treated) }\end{array}$} & \multicolumn{3}{|c|}{ Mocinga seed powder (mg/L) } & \multicolumn{3}{|c|}{$\begin{array}{l}\text { Residence time in magnetic } \\
\text { field } 1000 \mathrm{G}(100 \mathrm{mD}\end{array}$} & \multicolumn{3}{|c|}{$\begin{array}{l}\text { Moringa seed powder + residence time } \\
\text { in magnetic field }\end{array}$} \\
\hline & & 100 & 150 & 200 & $40 s$ & $60 \mathrm{~s}$ & $80 \mathrm{~s}$ & $\begin{array}{l}100 \mathrm{mg} / \mathrm{L} \\
+40 \mathrm{~s}\end{array}$ & $\begin{array}{l}100 \mathrm{mg} / \mathrm{L} \\
+60 \mathrm{~s}\end{array}$ & $\begin{array}{l}100 \mathrm{mg} / \mathrm{L} \\
+80 \mathrm{~s}\end{array}$ \\
\hline Turbidity (NTU) & 6.50 & 6.30 & 5.90 & 5.30 & 5.90 & 5.80 & 5.00 & 5.20 & 5.10 & 5.00 \\
\hline Reduction (\%) & 0.00 & 3.08 & 9.23 & 18.46 & 9.23 & 10.77 & 23.08 & 20.00 & 21.54 & 23.08 \\
\hline $\mathrm{pH}$ & 6.80 & 6.55 & 6.50 & 6.42 & 6.76 & 6.74 & 6.71 & 6.66 & 6.66 & 6.55 \\
\hline Reduction (\%) & 0.00 & 3.68 & 4.41 & 5.59 & 0.59 & 0.88 & 1.32 & 2.06 & 2.06 & 3.68 \\
\hline $\begin{array}{l}\text { Dissolved oxygen } \\
\text { (mg/L) }\end{array}$ & 160.00 & 147.20 & 124.80 & 120.00 & 128.00 & 124.80 & 105.60 & 110.40 & 104.40 & 96.00 \\
\hline Reduction (\%) & 0.00 & 8.00 & 22.00 & 25.00 & 20.00 & 22.00 & 34.00 & 31.00 & 34.75 & 40.00 \\
\hline $\mathrm{BOD}(\mathrm{mg} / \mathrm{L})$ & 98.00 & 97.20 & 94.00 & 91.00 & 97.20 & 96.80 & 95.60 & 95.80 & 92.60 & 89.80 \\
\hline Reduction (\%) & 0.00 & 0.82 & 4.08 & 7.14 & 0.82 & 1.22 & 2.45 & 2.24 & $\mathbf{5 . 5 1}$ & 8.37 \\
\hline $\mathrm{COD}(\mathrm{mg} / \mathrm{L})$ & 87.68 & 76.96 & 76.48 & 76.32 & 75.52 & 75.30 & 75.90 & 66.80 & 66.60 & 66.50 \\
\hline Reduction (\%) & 0.00 & 12.23 & 12.77 & 12.96 & 13.87 & 14.12 & 13.44 & 23.81 & 24.04 & 24.16 \\
\hline $\begin{array}{l}\text { Ammonia Nitrate } \\
\text { (mg/L) }\end{array}$ & 13.50 & 13.10 & 12.80 & 12.20 & 13.50 & 13.50 & 13.30 & 12.60 & 12.50 & 12.30 \\
\hline Reduction (\%) & 0.00 & 2.96 & 5.19 & 9.63 & 0.00 & 0.00 & 1.48 & 6.67 & 7.41 & 8.89 \\
\hline Sulphate ion $(\mathrm{mg} / \mathrm{L})$ & 32.68 & 30.92 & 30.55 & 30.46 & 31.52 & 31.50 & 31.46 & 30.68 & 30.44 & 30.31 \\
\hline Reduction $(\%)$ & 0.00 & 5.39 & 6.52 & 6.79 & 3.55 & 3.61 & 3.73 & 6.12 & 6.85 & 7.25 \\
\hline $\begin{array}{l}\text { Electrical Conductivity } \\
(\mathrm{gS} / \mathrm{cm})\end{array}$ & 10.59 & 10.57 & 10.53 & 10.41 & 10.55 & 10.50 & 10.47 & 10.56 & 10.45 & 10.32 \\
\hline $\begin{array}{l}\text { Reduction (\%) } \\
\text { Allalinity }\end{array}$ & $\begin{array}{l}\mathbf{0 . 0 0} \\
105.60\end{array}$ & $\begin{array}{l}0.19 \\
96.80\end{array}$ & $\begin{array}{l}\mathbf{0 . 5 7} \\
96.00\end{array}$ & $\begin{array}{l}1.70 \\
95.60\end{array}$ & $\begin{array}{l}\mathbf{0 . 3 8} \\
96.40\end{array}$ & $\begin{array}{l}0.85 \\
95.60\end{array}$ & $\begin{array}{l}1.13 \\
94.80\end{array}$ & $\begin{array}{l}0.28 \\
97.20\end{array}$ & $\begin{array}{l}\mathbf{1 . 3 2} \\
96.40\end{array}$ & $\begin{array}{l}\mathbf{2 . 5 5} \\
96.00\end{array}$ \\
\hline Reduction (\%) & 0.00 & 8.33 & 9.09 & 9.47 & 8.71 & 9.47 & 10.23 & 7.95 & 8.71 & 9.09 \\
\hline Total coliform & 190 & 27 & 22 & 30 & 120 & 110 & 100 & 47 & 36 & 23 \\
\hline$(\mathrm{sfy} / \mathrm{mL}) \times 10^{3}$ & 0.00 & 85.79 & 88.42 & 84.21 & 36.84 & 42.11 & 47.37 & 75.26 & 81.05 & 87.89 \\
\hline Reduction (\%) & & & & & & & & & & \\
\hline
\end{tabular}

Conclusion: Both magnetic field and moringa seed powder reduced the turbidity, alkalinity, $\mathrm{pH}$, BOD, COD, ammonia nitrate, sulphate ions and total coliform. Combination of magnetic field and moringa seed powder for wastewater treatment gave better and consistent percentage reduction of physical, chemical and bacteriological properties. Magnetic field had little effect on reduction of ammonia nitrate and sulphate ions which are essential for crop production. Combination of magnetic field and moringa seed powder is recommended for wastewater treatment in Nigeria.

\section{REFERENCES}

Adelaja, OA; Amoo, IA and Aderibigbe, AD (2011). Biosorption of Lead Ions from Aqueous Solution Using Moring oleifera Pods. Archives of Applied Science Research, 3: 50-60. 
Aladjadjiyan, A (2007). The use of physical methods for plant growing stimulation in Bulgaria. Journal of Central European Agriculture, 8 (3): 369-380.

Alkhazan, MMK and Sadddiq, AAN (2010). The effect of magnetic field on the physical, chemical and microbiological properties of the lake water in Saudi Arabia. Journal of Evolutionary Biology Research, 2 (1): 7-14.

Anne, T; Francis, N and Silas, K (2016). Effects of magnetic flux density on the population of Escherichia coli in River Njoro Water. International Journal of Physics, 4 (4): 113-118.

APHA (2005). Standard Methods for the Examination of Water and Wastewater, $21^{\text {st }}$ edition. Washington, DC: American Public Health Association.

Araújo, C; Melo, E; Alves, V and Coelho, N (2010). Moringa oleifera Lam. seeds as a natural solid adsorbent for removal of $\operatorname{Ag}(\mathrm{I})$ in aqueous solutions. Journal of Brazilian Chemical Society, 21 (9): 1727-1732

Barrett, RA and Persons, SA (1998). The Influence of Magnetic Fields on Calcium Carbonate Precipitation. Water Research. 32: 609-612.

Bhuptawat, H; Folkard, GK and Chaudhari, S (2007). Innovative Physico-Chemical Treatment of Wastewater Incorporating Moringa oleifera Seed Coagulant. Journal of Hazardous Materials, 142: 477-482.

Briggs, D (2003). Environmental pollution and the global burden of disease. British Medical Bulletin, 68 (1): 1-24.

Ejieji, CJ and Adeniran, KA (2009). Effect of water and fertilizer stress on the yield, fresh and dry matter production of grain amaranth. Australian Journal of Agricultural Engineering, 1 (1): 18-24.

Jung, J; Sanij, B; Godbole, S and Sofer, S (1997). Biodegradation of phenol: A comparative study with and without applying magnetic fields, Journal of Chemical Technology and Biotechnology. 56 (1): 73-76.

Kronenberg K (1985). Experimental evidence for the effects of magnetic fields on moving water. Transactions on Magnetics Institute of Electrical and Electronics Engineers, Inc., 21 (5): 20592066.

Ghebremichael, KA; Gunaratna, KR; Henriksson, H; Brumer, $H$ and Dalhammar, G (2005). Asimple purification and activity assay of the coagulant protein from Moringa Oleifera seed. Water Research, 39 (11): 2338-2344.

Lebkowska, M; Rutkowska-Narozniak, A; Pajor, E; and Pochanke, Z (2011). Effect of a static magnetic field on formaldehyde biodegradation in wastewater by activated sludge, Journal of Bioresource Technology, 102 (19): 8777-8782.

Liu, S; Yang, F; Meng, F; Chen, H and Gong, Z (2008). Enhanced anammox consortium activity for nitrogen removal: Impacts of static magnetic field, Journal of Biotechnology, 138: 96 - 102.

Kumari, P; Srivastava, S; Srivastava, M (2006). Biosorption studies on shelled Moringa oleifera Lamarck powder: Removal and recovery of arsenic from aqueous system. International Journal of Mineral Processing, 78 (3): 131-139.

Maheshwari, RL and Grewal, HS (2009). Magnetic treatment of irrigation water: its effects on vegetable crop yield and water productivity. Journal of Agricultural Water Management, 96 (8): 1229-1236.

Mustapha, HB (2013). A Review of the Applications of Moringa oleifera Seeds Extract in Water Treatment. Civil and Environmental Research, 3: 1-9.

Mdsa'at SK (2006). Subsurface flow and free water surface flow constructed wetland with magnetic field for leachate treatment. M.Eng. Thesis submitted to Faculty of Civil Engineering, University of Technology, Malaysia.

Ogunlela, AO (2001). Stochastic analysis of rainfall event in Ilorin, Nigeria. Journal of Agricultural Research and Development, 3: 39-49.

Ogunlela, AO and Yusuf, KO (2016). Effect of magnetic treatment of water on chemical properties of water and sodium adsorption ratio. J. Res. Forestry, Wildlife and Environ. 8 (4): 7379.

Othman, F; Sohaili, J; and Fausia, Z (2009). Influence of magnetic treatment on the improvement of landfill leachate treatment, Inter. J. Environ. Waste Manage. 4 (3-4): 433-444.

Podlesny, J; Pietruszewski, S and Podleoena, A (2004). Efficiency of the magnetic treatment of broad bean seeds cultivated under experimental plot conditions. Int. Agrophysics, 18: 65-71.

Shoaili, J; Fadil O and Zularisham A (2004). Effect of Magnetic Fields on Suspended Particles in Sewage. Malay J. Sci. 23: 141- 148. 